\title{
Estimation of the Nutrient Value of Agricultural Slurries by Measurement of Physical and Chemical Properties
}

\author{
I. M. Scotford ${ }^{1}$; T. R. Cumby ${ }^{1}$; R. P. White ${ }^{1}$; O. T. Carton ${ }^{2}$; F. Lorenz ${ }^{3}$; U. Hatterman ${ }^{3}$; G. Provolo ${ }^{4}$ \\ ${ }^{1}$ Silsoe Research Institute, Wrest Park, Silsoe, Bedford, MK454HS, UK; ${ }^{2}$ Teagasc, Johnstown Castle Research Centre, Wexford, Ireland; \\ ${ }^{3}$ LUFA, Jaegerstrasse 23-27, D-26121, Oldenburg, Germany; ${ }^{4}$ Universita Degli Studi di Milano, Instituto Di Ingegneria Agraria, Via Celoria 2, \\ 20133 Milano, Italy
}

(Received 19 January 1998; accepted in revised form 12 June 1998)

A prototype nutrient sensing system was used to investigate relationships between the nutrient status of agricultural slurries and a range of physical and chemical properties. These properties were all measured using devices suitable for possible installation in full-scale slurry handling systems. The prototype system was tested on a total of 160 slurries, comprising approximately 20 cattle and 20 pig slurries from each of four European countries. Linear relationships were identified between ammoniacal nitrogen concentration and the electrical conductivity of the slurries and between total phosphorus and the density of the slurries. Generally, regressions for total potassium were weaker than those identified for either ammoniacal nitrogen or total phosphorus. The results show that a practical nutrient sensing system is feasible for farm use. For example, such a system could be used on a slurry tanker to estimate the nutrient status of the whole tanker contents, thus eliminating the sampling errors associated with sub-sampling from a large store.

(C) 1998 Silsoe Research Institute

\section{Introduction}

Agricultural slurries contain useful amounts of the plant nutrients nitrogen $(\mathrm{N})$, phosphorus $(\mathrm{P})$ and potassi$\mathrm{um}(\mathrm{K}){ }^{1}$ However, the amounts of these nutrients available in a particular slurry are not easy to quantify without laboratory facilities. Thus, when agricultural slurries are applied to land, their fertilizer potential is often unknown. Hence, the spreading procedure becomes one of waste disposal rather than one of nutrient utilization, therefore increasing the risks of air, water and soil pollution.

In order to encourage farmers to make better use of slurry, and to reduce pollution risks, convenient methods and means are necessary to quantify the nutrients and to spread them efficiently and accurately in accordance with codes of good agricultural practice. ${ }^{2-4}$ Some machines are available that spread accurately on a volumetric basis, but these tend to be large and sophisticated and thus best suited to large farms or agricultural contractors. However, this technology is of limited use unless the nutrient status of the slurry can be determined easily and rapidly.

There are various methods available of reliable nutrient estimation on farms. For ammoniacal nitrogen, there are the $\operatorname{Agros}^{5}$ meter or Quantofix ${ }^{6}$ meters which use the hypochlorite-oxidation method and for total phosphorus there is the hydrometer. ${ }^{7}$ However, these methods rely on taking sub-samples of stored slurry. Without complete mixing of the store contents, the results are unlikely to represent the overall nutrient status. This is because random sampling from a large volume of settled slurry is unlikely to represent accurately the relative amounts of settled and unsettled material. Ideally, methods are required which can be used to measure the nutrient value of slurry either during transport or spreading. In principle, these methods could be used on a slurry tanker to determine the nutrient status of the whole contents of the tanker, thus avoiding sampling errors. Such applications require robust nutrient estimation methods with specific features including an electrical output signal and suitability for installation in a practical slurry handling system. For example, measurement of electrical conductivity (EC) meets these requirements and has been used previously ${ }^{8-10}$ to estimate the ammoniacal nitrogen content of slurries.

The range of properties which might provide useful practical estimates of plant nutrient concentrations in slurries has been reviewed previously. ${ }^{10}$ These properties were incorporated in a prototype nutrient sensing system $^{\mathbf{1 0}}$ and this paper details how this device was used in four European countries to measure a range of physical and chemical properties of agricultural slurries and to 
find relationships between them and the nutrient concentrations in the slurries. The best fitting regression equations were identified for estimating plant nutrients from the data gathered in each country. The nutrient sensing system included a selection of sensors with the required features for incorporation into a farm slurry spreading system. In consequence, the results that emerged from this investigation enabled the selection of appropriate sensors for a subsequent tanker-mounted prototype nutrient sensing system.

\section{Materials and methods}

\subsection{Prototype nutrient sensing system}

Full details of the prototype nutrient sensing system, its calibration and operation are provided elsewhere. ${ }^{10,11}$ The main features were as follows: (a) a commercially available submersible sonde containing sensors for redox potential, $\mathrm{pH}$, temperature, electrical conductivity with automatic temperature compensation (EC) and ammonium ions (AI); (b) a sample reservoir of approximately 601 capacity containing the sonde and a submersible grinder pump; (c) a loop of pipe with an internal diameter of $30 \mathrm{~mm}$ fed by the pump and returning the flow to the sample reservoir; (d) instruments installed in the loop of pipe included an in-line twin-tube vibrating density meter, an ultrasonic TS meter $\left(\mathrm{TS}_{\mathrm{u}}\right)$, a Doppler flowmeter and a differential pressure transducer to determine the pressure loss along a $21 \mathrm{~m}$ section of the pipe; (e) a manual sampling valve to enable collection of slurry samples from the loop of pipe for subsequent laboratory analysis and a manual in-line valve for varying slurry flow rates so that differential pressure could be determined at various flow rates; and (f) a personal computer (PC) to collect the data from the individual sensors.

\subsection{Slurry sample collection, data collection and slurry analysis}

The nutrient sensing system was used in the United Kingdom, Ireland, Germany and Italy. Approximately, 20 cattle and 20 pig slurries were tested in each country (Table 1). During the initial series of experiments in the United Kingdom, it was found that the ultrasonic TS meter $\left(\mathrm{TS}_{u}\right)$ did not work satisfactorily and this was subsequently removed from the system. In addition, it was noted that the redox sensor was set up incorrectly, thus no data on redox potential were obtained for the United Kingdom slurries; this was corrected before use in the other countries. In each of the countries, 501 slurry samples were collected from a wide range of differing
Table 1

Number of slurry samples collected in each European country

\begin{tabular}{ccccc}
\hline & \multicolumn{4}{c}{ Number of samples } \\
\cline { 2 - 5 } Slurry type & $\begin{array}{c}\text { United } \\
\text { Kingdom }\end{array}$ & Ireland & Germany & Italy \\
Cattle & 20 & 27 & 17 & 20 \\
Pig & 18 & 17 & 17 & 20 \\
Total & 38 & 44 & 34 & 40 \\
\hline
\end{tabular}

farming systems. Various storage periods could be tolerated between acquisition of the samples and their analysis because laboratory and nutrient sensing system procedures were undertaken concurrently. Therefore, any change in slurry properties affected both sets of results equally. Each of the samples was placed into the slurry reservoir and the circulation pump was operated for several minutes to ensure complete mixing. Data collection was then initiated using the PC; 15 sets of readings were taken before the liquid flow was progressively decreased by closing the in-line valve. The flow was decreased in steps of approximately 0.14 from $1.61 / \mathrm{s}$ to a minimum of $0.141 / \mathrm{s}$ before the valve was fully reopened. Several readings were taken at each flow rate so that a total of approximately 50 sets of readings were obtained for each sample. A 11 sub-sample of slurry was then collected for laboratory analysis of total solids (TS), total Kjeldahl nitrogen (TKN), ammoniacal nitrogen (AN), total phosphorus (P) and total potassium (K). The methods used for the laboratory analysis in each of the countries are detailed in Table 2. These methods were typical of those used in the respective countries to provide analytical service to commercial farmers. Comparison and harmonization of these methods was not the objective of this study, and therefore it was necessary to assume that the various laboratory procedures could produce differing analytical results between the countries involved. Therefore, the data were interpreted on a country-by-country basis to provide nutrient estimation procedures related to the estabilished local procedures.

\section{Results}

\subsection{Diversity of collected slurries}

The slurries investigated in this study (Tables 3 and 4) were collected from many different farming systems in four European countries, although they were not intended to be a representative sample of all slurries in those countries. The TS and TKN measurements were 
Table 2

Laboratory analysis methods used

\begin{tabular}{|c|c|c|c|c|}
\hline \multirow{2}{*}{$\begin{array}{l}\text { Measured } \\
\text { variable }\end{array}$} & \multicolumn{4}{|c|}{ Laboratory method used } \\
\hline & United Kingdom & Ireland & Germany & Italy \\
\hline $\begin{array}{l}\text { Total solids } \\
\text { (TS), } \%\end{array}$ & $\begin{array}{c}\text { Oven dyring at } 105^{\circ} \mathrm{C} \\
\text { for } 16 \mathrm{~h}\end{array}$ & $\begin{array}{l}\text { Oven drying at } \\
100^{\circ} \mathrm{C} \text { untill } \\
\text { constant weight }\end{array}$ & $\begin{array}{l}\text { Oven drying at } \\
105^{\circ} \mathrm{C} \text { for } 16 \mathrm{~h}\end{array}$ & $\begin{array}{c}\text { Oven drying at } \\
105^{\circ} \mathrm{C} \text { until constant } \\
\text { weight }\end{array}$ \\
\hline $\begin{array}{c}\text { Kjeldahl } \\
\text { nitrogen } \\
(\mathrm{TKN}), \mathrm{mg} / 1\end{array}$ & \multicolumn{4}{|c|}{ Digestion followed by steam distillation } \\
\hline $\begin{array}{l}\text { Ammoniacal } \\
\text { nitrogen } \\
(\mathrm{AN}), \mathrm{mg} / 1\end{array}$ & \multicolumn{2}{|c|}{ Steam distillation } & $\begin{array}{l}\text { Ammonia } \\
\text { sensitive } \\
\text { electrode }\end{array}$ & Steam distillation \\
\hline $\begin{array}{c}\text { Total } \\
\text { phosphorus } \\
\text { (P), mg/1 }\end{array}$ & $\begin{array}{c}\text { ICP (inductively } \\
\text { coupled plasma } \\
\text { spectrophotometry) }\end{array}$ & $\begin{array}{l}\text { Digestion } \\
\text { followed by } \\
\text { autoanalyser }\end{array}$ & $\begin{array}{l}\text { Digestion } \\
\text { followed by } \\
\text { colorimetry }\end{array}$ & $\begin{array}{l}\text { Digestion followed } \\
\text { by } \\
\text { spectrophotometry }\end{array}$ \\
\hline $\begin{array}{l}\text { Total } \\
\text { potassium } \\
(\mathrm{K}), \mathrm{mg} / 1\end{array}$ & \multicolumn{2}{|c|}{$\begin{array}{l}\text { Digestion followed by atomic absorption } \\
\text { spectrophotometry }\end{array}$} & \multicolumn{2}{|c|}{$\begin{array}{l}\text { Digestion followed by flame } \\
\text { photometry }\end{array}$} \\
\hline
\end{tabular}

used solely as indicators of slurry concentration; the wide ranges of these values, $0 \cdot 27-9 \cdot 81 \%$ and $181-8340 \mathrm{mg} / 1$, respectively, illustrated that a comprehensive selection of slurries was used. Values of these properties were not used for the subsequent data analysis.

Comparing the $\mathrm{AN}, \mathrm{P}$, and $\mathrm{K}$ concentrations identified in this study with the typical nutrient contents ${ }^{12}$ of cattle slurries $(\mathrm{AN}=1300 \mathrm{mg} / \mathrm{l}, \mathrm{P}=600 \mathrm{mg} / \mathrm{l}, \mathrm{K}=2800 \mathrm{mg} / \mathrm{l})$ and pig slurries $(\mathrm{AN}=3000 \mathrm{mg} / \mathrm{l}, \quad \mathrm{P}=1500 \mathrm{mg} / \mathrm{l}$, $\mathrm{K}=2700 \mathrm{mg} / \mathrm{l}$ ) shows that the slurries collected ranged both above and below these typical figures.

\subsection{Data analysis}

The amount of data from each experiment was reduced by calculating an average value from the 50 readings obtained, during a typical test run, for each measured property except flow and differential pressure. Instead, these values were used to derive $\ln (k)$, a term associated with the rheological properties of the slurry defined by the following relationship:

$$
\ln (k)=\ln (\tau)-n \ln (\gamma)
$$

where $\tau$ is the shear stress, $\mathrm{Pa} ; \gamma$ the shear rate, $\mathrm{s}^{-1}$; and $k$ and $n$ are parameters for each slurry.

The procedures to determine $\ln (k)$ and $n$ for each slurry sample are detailed elsewhere. ${ }^{10,13}$

To facilitate statistical analysis the data were split into four groups, each group representing one country. In each case, the average values determined from the individual sensors and the derived values of $\ln (k)$ were compared with $\mathrm{AN}, \mathrm{P}$ and $\mathrm{K}$ concentrations derived from the laboratory analyses. It was suspected that these concentrations might, in some instances, be related to more than one of the measured properties. Therefore, the following generalized equation was used in linear regressions analyses:

$$
Y=w C_{i}+x C_{j}+z
$$

where $Y=\mathrm{AN}, \mathrm{P}$ or $\mathrm{K}, \mathrm{mg} / \mathrm{l} ; w, x, z$ are regression coefficients and $C_{i}, C_{j}$ are the measured properties.

Single and multiple properties regressions were fitted using the Genstat program ${ }^{14}$ (the coefficient $x$ was assigned a value of zero for the purposes of single property regression). Alternative regression models were considered representing cattle and pig slurries either as two independent populations, or as one combined population. The most appropriate were selected using a "forward selection procedure". 15 The statistical analysis was designed to provide predictive models for subsequent use, without excessive complexity. The details of the statistical procedures are described in the Appendix 1.

The single regressions were completed first and the resulting relationships between concentrations of the key nutrients ( $\mathrm{AN}, \mathrm{P}$ and $\mathrm{K}$ ) and each of the measured properties were compared to find those which provided the best fit to the data, i.e. those which gave high values of 
Table 3

Comparison of the minimum, maximum and mean for total solids, Kjeldahl nitrogen, ammoniacal nitrogen, total phosphorus and total potassium for cattle slurries in each of the participating countries

\begin{tabular}{|c|c|c|c|c|c|}
\hline $\begin{array}{l}\text { Property measured by } \\
\text { laboratory analysis }\end{array}$ & & $\begin{array}{l}\text { United } \\
\text { Kingdom }\end{array}$ & Ireland & Germany & Italy \\
\hline \multirow[t]{3}{*}{ Total solids (TS), \% } & Minimum & $0 \cdot 27$ & $1 \cdot 60$ & $1 \cdot 30$ & $0 \cdot 60$ \\
\hline & Maximum & $8 \cdot 34$ & $7 \cdot 10$ & $5 \cdot 04$ & $4 \cdot 15$ \\
\hline & Mean & 3.58 & 3.02 & 3.61 & $2 \cdot 54$ \\
\hline \multirow{3}{*}{$\begin{array}{l}\text { Kjeldahl nitrogen } \\
(\mathrm{TKN}), \mathrm{mg} / \mathrm{l}\end{array}$} & Minimum & 181 & 700 & 685 & 500 \\
\hline & Maximum & 5050 & 3970 & 4700 & 2200 \\
\hline & Mean & 1890 & 1610 & 2280 & 1260 \\
\hline \multirow{3}{*}{$\begin{array}{l}\text { Ammoniacal nitrogen } \\
\text { (AN), mg/l }\end{array}$} & Minimum & 94 & 390 & 363 & 20 \\
\hline & Maximum & 2120 & 2150 & 4000 & 1120 \\
\hline & Mean & 767 & 915 & 1410 & 435 \\
\hline \multirow{3}{*}{$\begin{array}{l}\text { Total Phosphorus (P), } \\
\text { mg/l }\end{array}$} & Minimum & 28 & 100 & 114 & 40 \\
\hline & Maximum & 515 & 730 & 624 & 910 \\
\hline & Mean & 310 & 271 & 329 & 237 \\
\hline \multirow{3}{*}{$\begin{array}{l}\text { Total potassium (K), } \\
\mathrm{mg} / \mathrm{l}\end{array}$} & Minimum & 135 & 650 & 719 & 70 \\
\hline & Maximum & 2020 & 5550 & 5810 & 4780 \\
\hline & Mean & 753 & 2290 & 2430 & 1150 \\
\hline
\end{tabular}

percentage variance accounted for (pva). Subsequently, the multiple regressions technique was applied using a subset of the measured properties. The combinations of properties included in this subset were selected by inspection of the results of the single regressions. Upon completion of the linear regressions, the resulting residual deviations of the data were examined for systematic effects; none was found and this indicated that there was no clear justification for considering more complex models.

The best-fit single and multiple regressions were used to evaluate forecast standard errors (fse) to indicate the likely accuracy with which nutrients could be estimated in future slurry samples. Since these fse values were dependent upon the values of the properties measured by the individual sensors, the procedure was undertaken at the 10 and $90 \%$ quantile values of the measured properties. This procedure was completely separate for cattle and pig slurries. In situations where multiple regressions provided the best fit, the procedure was completed for each combination of the 10 and $90 \%$ quantiles of each measured property

The best-fit single property regressions are presented in Figs 1-14 and the regression coefficients of the best-fit multiple property regressions are presented in Tables 5 , 6 and 7 or AN, P and K, respectively.

\subsection{Ammoniacal nitrogen}

In the United Kingdom, Ireland and Germany, the best single property regressions for $\mathrm{AN}$ were with electrical conductivity (EC) (Figs 1-3), with pva values of $84 \cdot 1$, 80.6 and $91.9 \%$, respectively. In Italy, the regressions of AN with all of the measured properties produced pva values of less than $50 \%$. For example, the regression of AN with EC gave a pva value of $39 \cdot 1 \%$ (Fig. 4). The best regression identified for Italian AN was with $\ln (k)$, which had a pva value of $45.5 \%$ (Fig. 5) although the weakly negative slope of the regression line for cattle slurries suggests that the AN concentration in only the pig slurries could be reliably estimated in this way.

In the United Kingdom and Italy the best-fit multiple property regressions for AN included EC and $\ln (k)$ (pva values of $85 \cdot 1$ and $50 \cdot 1$, respectively). In Ireland and Germany, the best-fit multiple property regressions for AN included EC and density (pva values of 83.4 and $92.5 \%$, respectively) (Table 5). The data from the United Kingdom, Ireland and Germany showed that the multiple property regressions for $\mathrm{AN}$ which included EC were consistently superior to all others. In contrast, this strong relationship between $\mathrm{AN}$ and $\mathrm{EC}$ was less apparent from the Italian data; the pva values from 
Table 4

Comparison of the minimum, maximum and mean for total solids, Kjeldahl nitrogen, ammoniacal nitrogen, total phosphorus and total potassium for pig slurries in each of the participating countries

\begin{tabular}{|c|c|c|c|c|c|}
\hline $\begin{array}{l}\text { Property measured by } \\
\text { laboratory analysis }\end{array}$ & & $\begin{array}{l}\text { United } \\
\text { Kingdom }\end{array}$ & Ireland & Germany & Italy \\
\hline \multirow[t]{2}{*}{ Total solids (TS), \% } & $\begin{array}{l}\text { Minimum } \\
\text { Maximum }\end{array}$ & $\begin{array}{l}0 \cdot 50 \\
7 \cdot 16\end{array}$ & $\begin{array}{l}0.53 \\
6.90\end{array}$ & $\begin{array}{l}1 \cdot 80 \\
6 \cdot 50\end{array}$ & $\begin{array}{l}0 \cdot 79 \\
9 \cdot 81\end{array}$ \\
\hline & Mean & $3 \cdot 32$ & 2.52 & 4.53 & $3 \cdot 15$ \\
\hline \multirow[t]{2}{*}{$\begin{array}{l}\text { Kjeldahl nitrogen } \\
\text { (TKN), mg/l }\end{array}$} & $\begin{array}{l}\text { Minimum } \\
\text { Maximum }\end{array}$ & $\begin{array}{r}824 \\
8340\end{array}$ & $\begin{array}{r}550 \\
5200\end{array}$ & $\begin{array}{l}2200 \\
6900\end{array}$ & $\begin{array}{r}700 \\
7100\end{array}$ \\
\hline & Mean & 4240 & 2700 & 4870 & 3410 \\
\hline \multirow[t]{2}{*}{$\begin{array}{l}\text { Ammoniacal nitrogen } \\
\text { (AN), mg/l }\end{array}$} & $\begin{array}{l}\text { Minimum } \\
\text { Maximum }\end{array}$ & $\begin{array}{r}616 \\
5600\end{array}$ & $\begin{array}{r}629 \\
3950\end{array}$ & $\begin{array}{l}1450 \\
5100\end{array}$ & $\begin{array}{r}200 \\
3510\end{array}$ \\
\hline & Mean & 2690 & 2140 & 3620 & 1400 \\
\hline \multirow[t]{2}{*}{$\begin{array}{l}\text { Total Phosphorus (P), } \\
\mathrm{mg} / \mathrm{l}\end{array}$} & $\begin{array}{l}\text { Minimum } \\
\text { Maximum }\end{array}$ & $\begin{array}{r}38 \\
2330\end{array}$ & $\begin{array}{r}50 \\
1800\end{array}$ & $\begin{array}{r}262 \\
1750\end{array}$ & $\begin{array}{r}80 \\
1770\end{array}$ \\
\hline & Mean & 694 & 626 & 1162 & 642 \\
\hline \multirow[t]{2}{*}{$\begin{array}{l}\text { Total potassium (K), } \\
\mathrm{mg} / \mathrm{l}\end{array}$} & $\begin{array}{l}\text { Minimum } \\
\text { Maximum }\end{array}$ & $\begin{array}{r}328 \\
1520\end{array}$ & $\begin{array}{r}450 \\
3200\end{array}$ & $\begin{array}{l}1266 \\
4400\end{array}$ & $\begin{array}{r}290 \\
5690\end{array}$ \\
\hline & Mean & 988 & 1850 & 2990 & 1720 \\
\hline
\end{tabular}

all of the multiple regressions were between 20 and $50.1 \%$.

The statistical analysis showed that the best-fit relationships for the data from the United Kingdom and Germany were provided by single property regressions between $\mathrm{AN}$ and $\mathrm{EC}$, leading to fse values ranging from \pm 548 to $\pm 571 \mathrm{mg} / \mathrm{l}$ and from \pm 442 to $\pm 457 \mathrm{mg} / \mathrm{l}$, respectively. In Ireland and Italy, multiple property regressions were better. In the former, AN was related to $\mathrm{EC}$ and density (fse values ranging from \pm 375 to $\pm 407 \mathrm{mg} / \mathrm{l})$ and in the latter AN related to EC and $\ln (k)$ (fse values ranging from \pm 710 to $\pm 801 \mathrm{mg} / \mathrm{l}$ ).

\subsection{Total phosphorus}

The total phosphorus in most cattle and pig slurries is largely insoluble, and it was therefore expected that $\mathrm{P}$ would relate to properties reflecting the total solids content of the slurries, i.e. density and $\ln (k)$. The single property regressions in Ireland, Germany and Italy showed that this was the case; regressions of $\mathrm{P}$ with density (Figs 6-8) produced pva values of $64 \cdot 8,83.6$ and $76 \cdot 1 \%$, respectively. The second best regression in each of these countries was with $\ln (k)$ with respective pva values of $22 \cdot 3,75 \cdot 8$ and $59 \cdot 0 \%$. In all cases, the statistical analysis indicated that separate regression equations were required for pig slurries and cattle slurries. In the United Kingdom, the equivalent regressions were not as good; all had pva values of less than $50 \%$. For example, the regression of $\mathrm{P}$ with density had a pva value of $35.8 \%$ (Fig. 9). The best regression for United Kingdom $\mathrm{P}$ was with the $\mathrm{pH}$ with a pva value of $45 \cdot 6 \%$ (Fig. 10). Again, separate regression equations were required for pig slurries and cattle slurries.

For all four countries, the best-fit multiple property regressions for $\mathrm{P}$ included density and either $\mathrm{pH}$ in the United Kingdom and Italy or $\ln (k)$ in Ireland and Germany with respective pva values of $67 \cdot 0,82 \cdot 0,69 \cdot 7$ and $89.9 \%$ (Table 6). Overall, the general observation was that those multiple property regressions which included density had higher pva values than those which did not.

Although the single property regressions showed that the $\mathrm{P}$ concentrations of the slurries tested were related to density, the best results were achieved in all four countries using multiple property regressions of $\mathrm{P}$ with density and $\mathrm{pH}$ leading to fse values ranging from \pm 308 to $\pm 322 \mathrm{mg} / 1$ (United Kingdom) and from \pm 192 to 


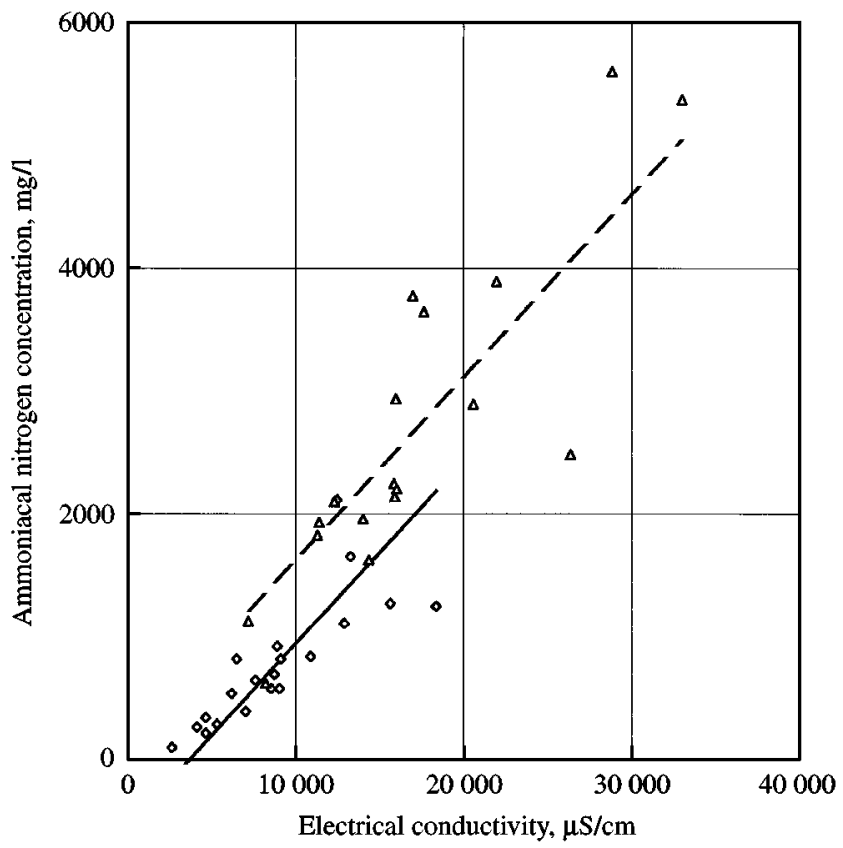

Fig. 1. Relationship between ammoniacal nitrogen (AN) concentration and electrical conductivity (EC) for UK slurries $\diamond$, cattle slurry; $\triangle$, pig slurry; $\longrightarrow, A N_{\text {cattle }}=0 \cdot 149 E C-552$ (fitted); ----, $A N_{\mathrm{pig}}=0.149 E C+131$ (fitted); percentage variance accounted for $84.1 \%, p<0 \cdot 01$

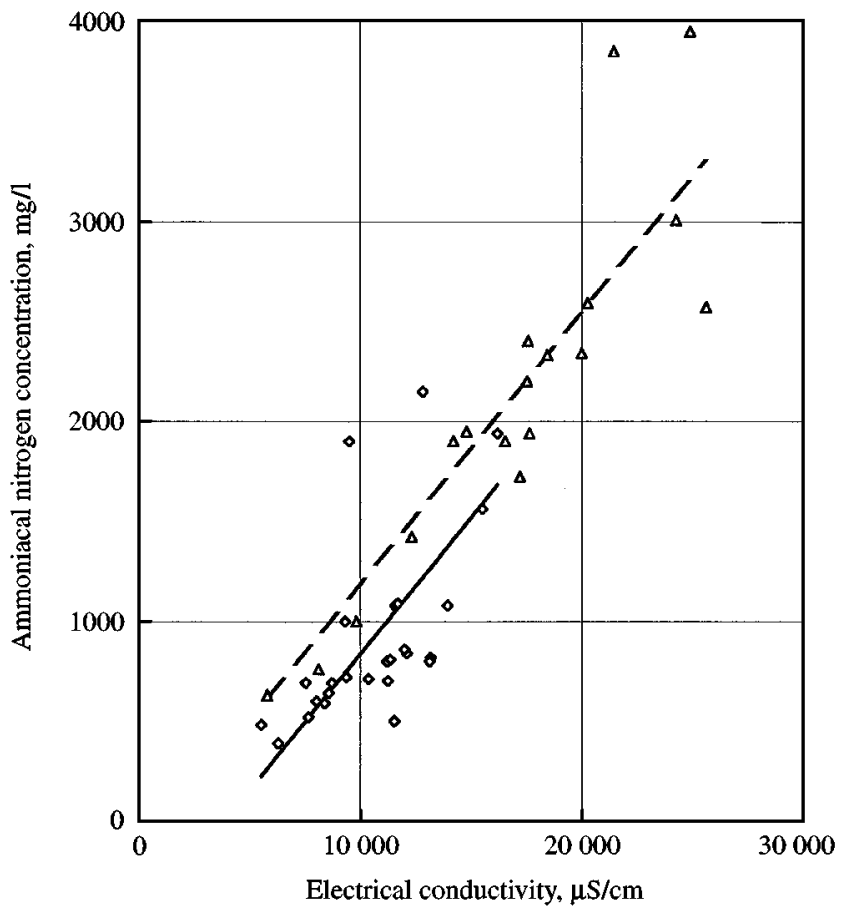

Fig. 2. Relationship between ammoniacal nitrogen (AN) concentration and electrical conductivity (EC) for Irish slurries $\diamond$, cattle slurry; $\triangle$, pig slurry; $\longrightarrow, A N_{\text {cattle }}=0.136 E C-523$ (fitted); ----, $A N_{\mathrm{pig}}=0.136 \mathrm{EC}-174$ (fitted); percentage variance accounted for $80 \cdot 6 \%, p<0 \cdot 01$

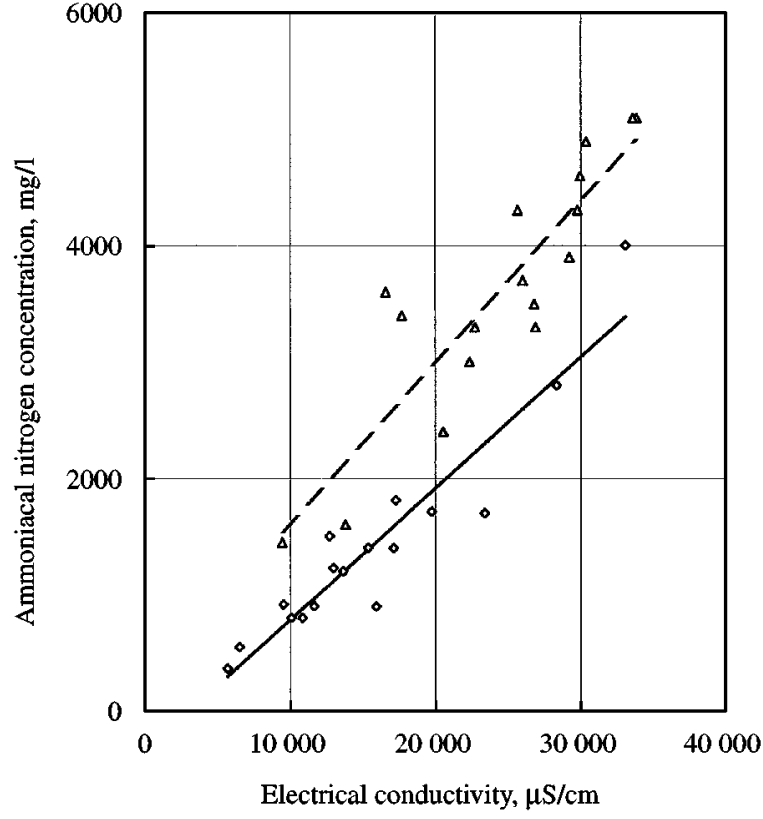

Fig. 3. Relationship between ammoniacal nitrogen (AN) concentration and electrical conductivity (EC) for German slurries $\diamond$, cattle slurry; $\triangle$, pig slurry;,$- A N_{\text {cattle }}=0 \cdot 113 E C-348$ (fitted); ----, $A N_{\mathrm{pig}}=0.139 \mathrm{EC}+217$ (fitted); percentage variance accounted for $91.9 \%, p<0.01$

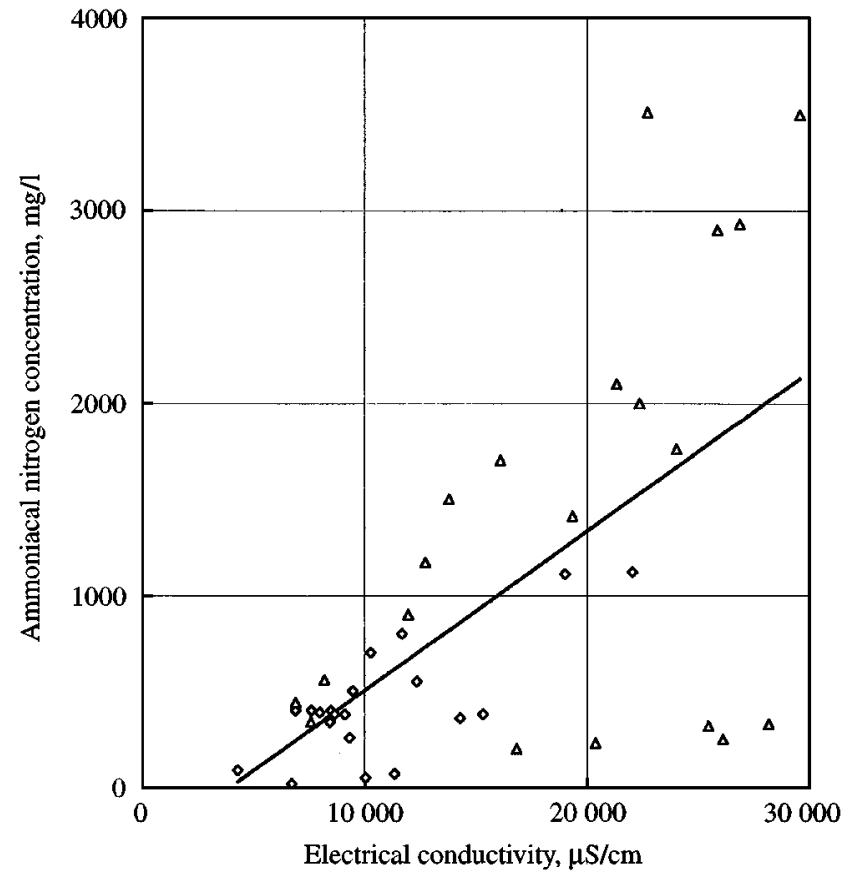

Fig. 4. Relationship between ammoniacal nitrogen (AN) concentration and electrical conductivity (EC) for Italian slurries $\diamond$, cattle slurry; $\triangle$, pig slurry; - $\quad A N_{\text {cattle and pig }}=0.083$ $E C-327$ (fitted); percentage variance accounted for $39 \cdot 1 \%$,

$$
p<0 \cdot 01
$$




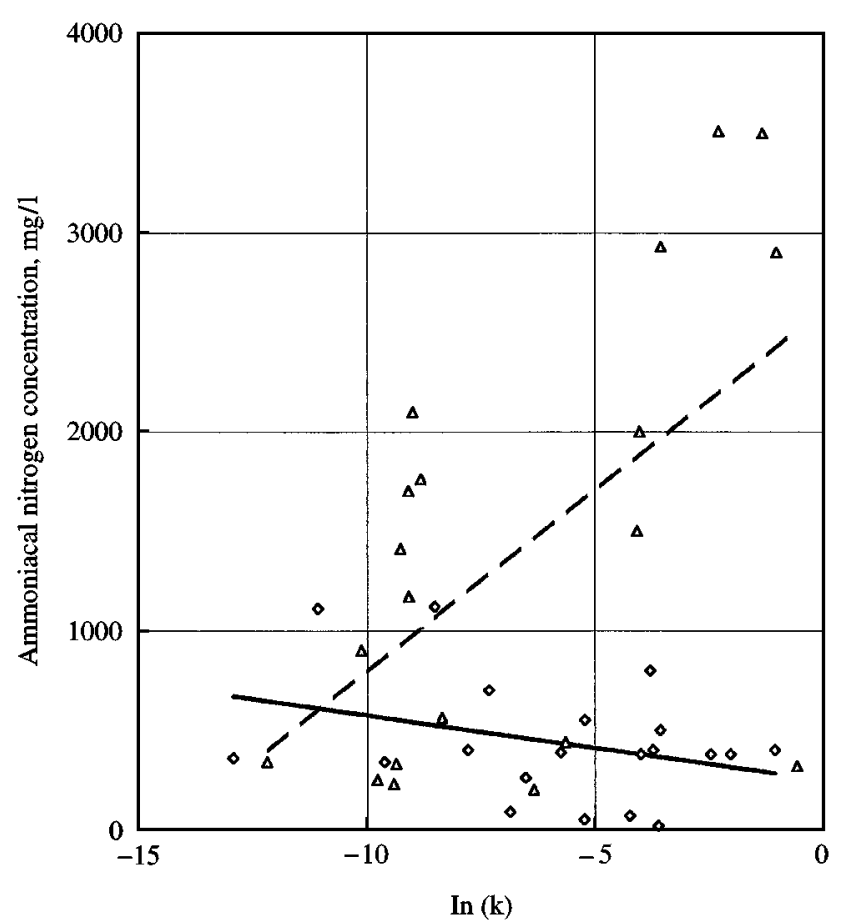

Fig. 5. Relationship between ammoniacal nitrogen (AN) concentration and $\ln (k)$ for Italian slurries $\diamond$, cattle slurry; $\triangle$, pig slurry; ,$- A N_{\text {cattle }}=-32 \cdot 5(\mathrm{k})+248$ (fitted); ----, $A N_{\text {pig }}=182 \cdot 2$ $\ln (k)+2619$ (fitted); percentage variance accounted for $45 \cdot 5 \%$,

$$
p<0 \cdot 01
$$

$\pm 203 \mathrm{mg} / \mathrm{l}$ (Italy); or with density and $\ln (k)$ leading to fse values ranging from \pm 234 to $\pm 293 \mathrm{mg} / \mathrm{l}$ (Ireland) and from \pm 185 to $\pm 268 \mathrm{mg} / \mathrm{l}$ (Germany).

\subsection{Total potassium}

The single property regressions between $\mathrm{K}$ and the measured properties in the four countries were generally weak and not as good as either the $\mathrm{AN}$ or P regressions. In Ireland and Germany, the best regressions for $\mathrm{K}$ were with EC (Figs 11 and 12), with pva values of $19 \cdot 2$ and $80.0 \%$, respectively. In the United Kingdom, surprisingly, the best regression for $\mathrm{K}$ was with ammonium ions (AI) (Fig. 13); the pva value of the regression was $50 \cdot 2 \%$. In Italy, the best regression for K was with density (Fig. 14) with a pva value of $42 \cdot 4 \%$.

Similarly, the multiple property regressions were generally not as good for $\mathrm{K}$ as those for either AN or $\mathrm{P}$ (Table 7). The German data provided an exception to this; the regression of $\mathrm{K}$ on $\mathrm{EC}$ and density produced a pva value of $84.8 \%$. The best fit multiple property regressions for $\mathrm{K}$ in Ireland and Italy were also with EC and density with respective pva values of 27.9 and $56.4 \%$. In the United Kingdom, the best-fit multiple property

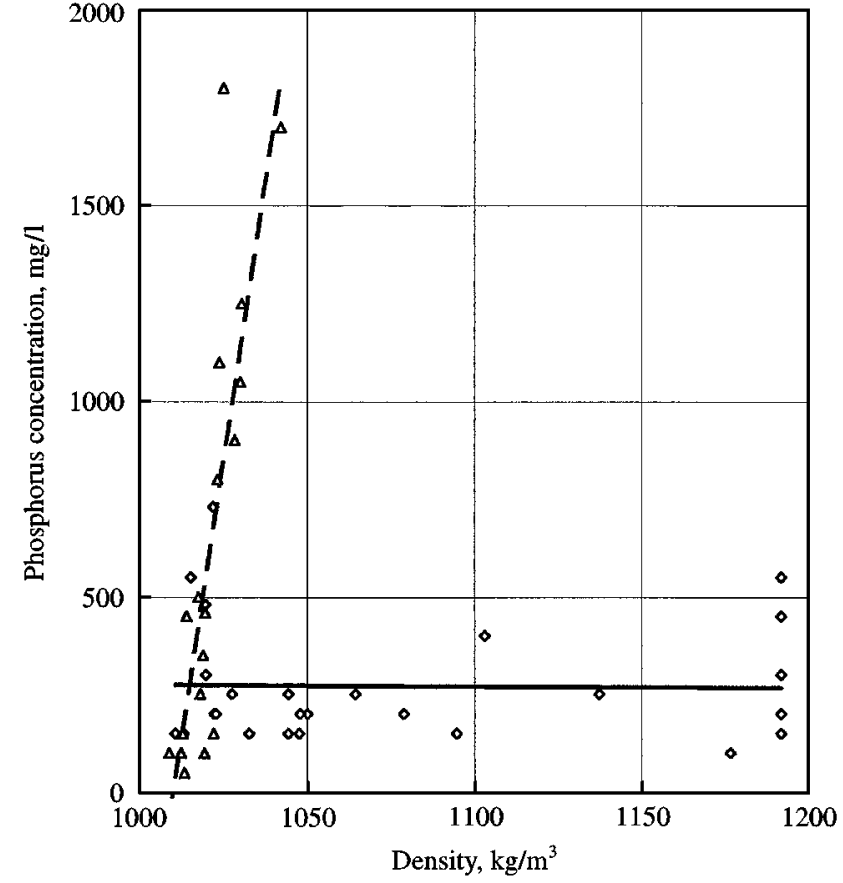

Fig. 6. Relationship between total phosphorus $(P)$ concentration and density $(\rho)$ for Irish slurries $\diamond$, cattle slurry; $\triangle$, pig slurry; $\longrightarrow, P_{\text {cattle }}=-0.041 \rho+315$ (fitted); ----, $P_{\text {pig }}=56 \cdot 86 \rho-$ 57426 (fitted); percentage variance accounted for $64 \cdot 8 \%, p<0 \cdot 01$

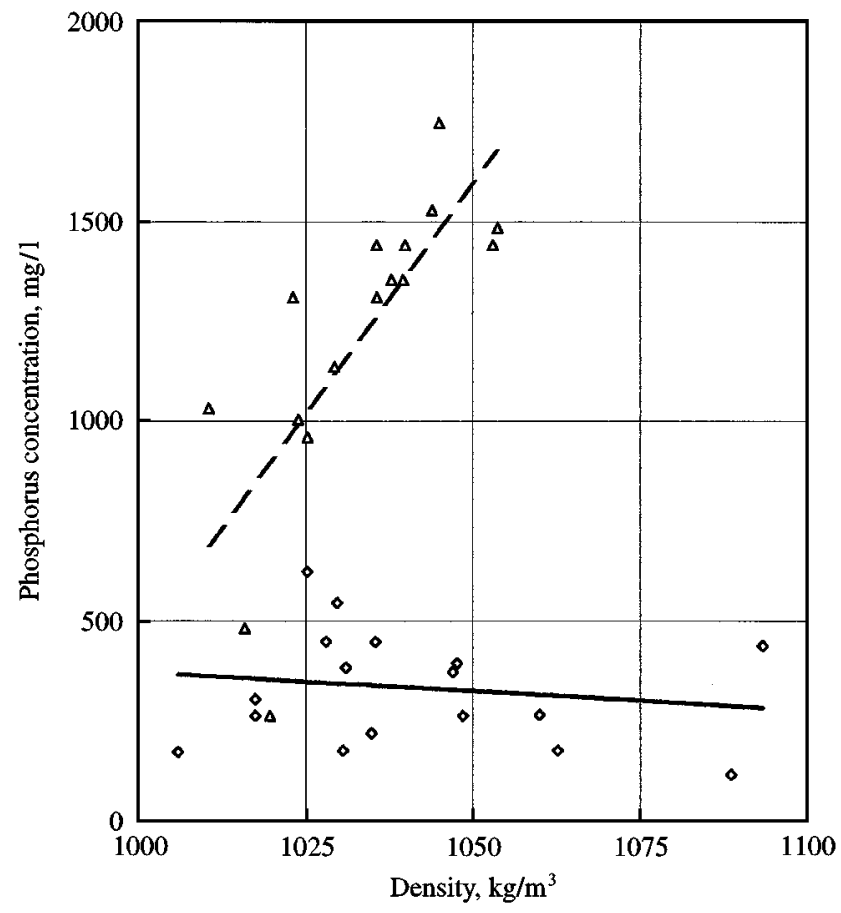

Fig. 7. Relationship between total phosphorus $(P)$ concentration and density $(\rho)$ for German slurries $\diamond$, cattle slurry; $\triangle$, pig slurry; $\longrightarrow, P_{\text {cattle }}=-0.96 \rho+1331$ (fitted); ----, $P_{\text {pig }}=23.06 \rho-$ 22618 (fitted); percentage variance accounted for $83.6 \%, p<0 \cdot 01$ 
Table 5

Best fit multiple property regressions coefficients (and associated standard errors) for ammoniacal nitrogen

\begin{tabular}{|c|c|c|c|c|c|c|}
\hline \multirow[b]{2}{*}{ slurry type } & \multicolumn{3}{|c|}{ Regression coefficients } & \multicolumn{2}{|c|}{ Measured properties } & \multirow[b]{2}{*}{$p v a(p)$} \\
\hline & $w$ & $x$ & $z$ & $C_{i}$ & $C_{j}$ & \\
\hline $\begin{array}{l}\text { United } \\
\text { Kingdom } \\
\text { cattle }\end{array}$ & $\begin{array}{c}0 \cdot 154 \\
(0 \cdot 018)\end{array}$ & $\begin{array}{l}-38 \cdot 7 \\
(38 \cdot 0)\end{array}$ & $\begin{array}{l}-749 \\
(247)\end{array}$ & \multirow{2}{*}{$\begin{array}{c}\text { Electrical } \\
\text { conductivity }\end{array}$} & \multirow{2}{*}{$\ln (k)$} & \multirow{2}{*}{$\begin{array}{c}85 \cdot 1 \\
(p<0 \cdot 01)\end{array}$} \\
\hline $\begin{array}{l}\text { United } \\
\text { Kingdom } \\
\text { Pigs }\end{array}$ & $\begin{array}{c}0 \cdot 154 \\
(0 \cdot 018)\end{array}$ & $\begin{array}{l}-38 \cdot 7 \\
(38 \cdot 0)\end{array}$ & $\begin{array}{l}-98 \\
(383)\end{array}$ & & & \\
\hline Irish cattle & $\begin{array}{c}0 \cdot 129 \\
(0 \cdot 014)\end{array}$ & $\begin{array}{l}-0 \cdot 83 \\
(1 \cdot 03)\end{array}$ & $\begin{array}{c}452 \\
(1105)\end{array}$ & \multirow{2}{*}{$\begin{array}{l}\text { Electrical } \\
\text { conductivity }\end{array}$} & \multirow{2}{*}{ density } & \multirow{2}{*}{$\begin{array}{c}83.4 \\
(p<0.01)\end{array}$} \\
\hline Irish pigs & $\begin{array}{c}0 \cdot 129 \\
(0 \cdot 014)\end{array}$ & $\begin{array}{c}33 \cdot 1 \\
(11 \cdot 0)\end{array}$ & $\begin{array}{l}-33866 \\
(11170)\end{array}$ & & & \\
\hline $\begin{array}{l}\text { German } \\
\text { cattle }\end{array}$ & $\begin{array}{l}0 \cdot 1133 \\
(0 \cdot 014)\end{array}$ & $\begin{array}{l}-0.60 \\
(4 \cdot 05)\end{array}$ & $\begin{array}{c}275 \\
(4225)\end{array}$ & \multirow{2}{*}{$\begin{array}{c}\text { Electrical } \\
\text { conductivity }\end{array}$} & \multirow{2}{*}{ density } & \multirow{2}{*}{$\begin{array}{c}92.5 \\
(p<0.01)\end{array}$} \\
\hline $\begin{array}{l}\text { German } \\
\text { pigs }\end{array}$ & $\begin{array}{c}0 \cdot 1362 \\
(0 \cdot 0159)\end{array}$ & $\begin{array}{l}-0.60 \\
(4 \cdot 05)\end{array}$ & $\begin{array}{c}947 \\
(4068)\end{array}$ & & & \\
\hline $\begin{array}{l}\text { Italian } \\
\text { cattle }\end{array}$ & $\begin{array}{l}0 \cdot 0426 \\
(0 \cdot 020)\end{array}$ & $\begin{array}{l}-10 \cdot 5 \\
(51 \cdot 1)\end{array}$ & $\begin{array}{l}-79 \\
(361)\end{array}$ & \multirow{2}{*}{$\begin{array}{c}\text { Electrical } \\
\text { conductivity }\end{array}$} & \multirow{2}{*}{$\ln (k)$} & \multirow{2}{*}{$\begin{array}{c}50 \cdot 1 \\
(p<0 \cdot 01)\end{array}$} \\
\hline Italian pigs & $\begin{array}{l}0 \cdot 0426 \\
(0 \cdot 020)\end{array}$ & $\begin{array}{l}143 \cdot 6 \\
(47 \cdot 2)\end{array}$ & $\begin{array}{l}1539 \\
(613)\end{array}$ & & & \\
\hline
\end{tabular}

$\mathrm{p} v \mathrm{a}=$ percentage variance accounted for; $\quad p=$ level of significance.

regression was with the sensor-derived properties $\mathrm{AI}$ and $\mathrm{pH}$ yielding a pva value of $49 \cdot 0 \%$.

The $\mathrm{K}$ concentrations in the slurries were generally related to EC and density. In Germany and Italy, the best results were achieved using multiple property regressions of $\mathrm{K}$ with $\mathrm{EC}$ and density (fse values ranging from \pm 499 to $\pm 547 \mathrm{mg} / 1$ and from \pm 811 to $\pm 868 \mathrm{mg} / 1$, respectively). In Ireland, the best fit was $\mathrm{K}$ with $\mathrm{EC}$ alone (fse values ranging from \pm 1033 to $\pm 1084 \mathrm{mg} / \mathrm{l})$. It should be noted that even though the pva for the best-fit multiple property regression for the Irish $\mathrm{K}$ was $27.9 \%$ compared with $19 \cdot 2 \%$ for the single property regression, the single property regression was superior since addition of the density term was not statistically significant. The best fit in the United Kingdom for K was a single property regression with $\mathrm{AI}$ (fse values ranging from \pm 297 to $\pm 306 \mathrm{mg} / \mathrm{l})$.

\section{Discussion}

As noted in Section 1, the purpose of this investigation was to identify appropriate sensors for use in a prototype tanker-mounted nutrient-sensing system. Single property regressions revealed general relationships between each of the nutrients examined ( $\mathrm{AN}, \mathrm{P}$ and $\mathrm{K}$ ) and the measured properties in all four countries. For AN, in three of the countries, the best regression was found to be with EC. It could therefore be argued, for simplicity, that EC should also be used in the fourth country (Italy) despite not achieving the best fit on this particular set of data. Similarly, for $\mathrm{P}$, density gave the best single property regression, except in the United Kingdom. Thus, it could also be argued that density should be used in the United Kingdom despite this not being the best regression identified with this data set. For K, there was no particular property that was best in all countries.

Multiple property regressions highlighted general patterns across the countries. In the case of $\mathrm{AN}$, the best regressions were with $\mathrm{EC}$ and density in Ireland and Germany, and with EC and $\ln (k)$ in the United Kingdom and Italy. However, since both density and $\ln (k)$ are associated with the TS of the slurry, it could be argued that either could be used with EC to form a standard multiple property regression applicable in all four countries. For $\mathrm{P}$, the best regressions were with density and 


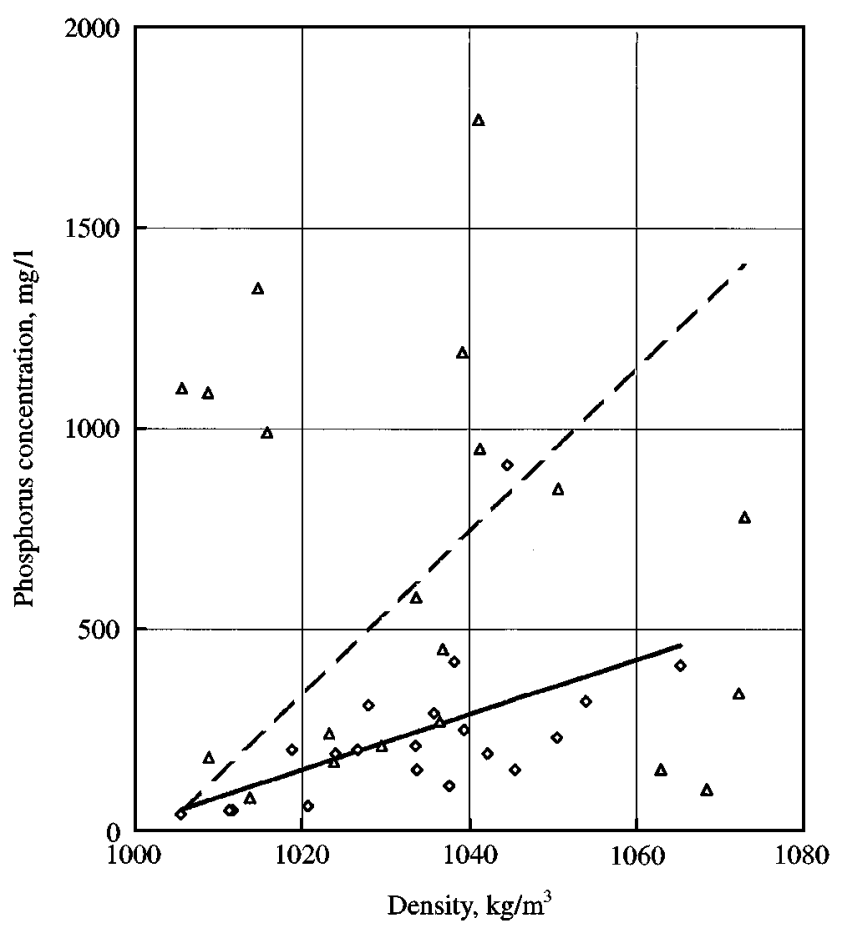

Fig. 8. Relationship between total phosphorus $(P)$ concentration and density $(\rho)$ for Italian slurries $\diamond$, cattle slurry; $\triangle$, pig slurry; $\longrightarrow, P_{\text {cattle }}=6.85 \rho-6837$ (fitted); ----, $P_{\text {pig }}=20 \cdot 25 \rho-20317$ (fitted); percentage variance accounted for $76 \cdot 1 \%, p<0.01$

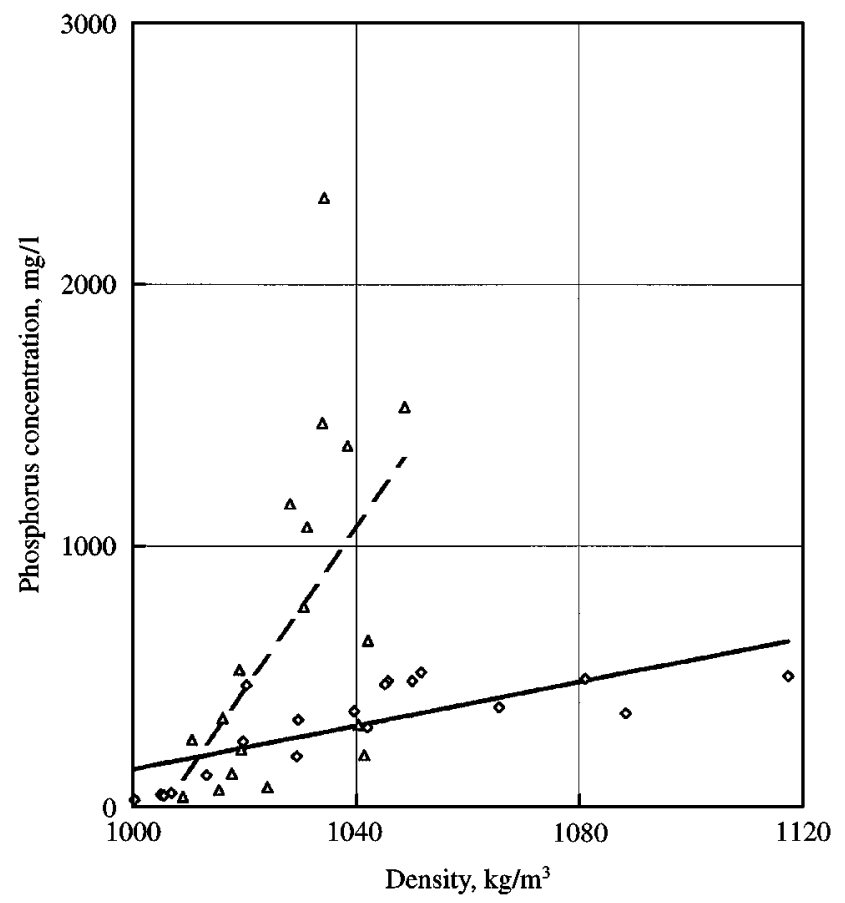

Fig. 9. Relationship between total phosphorus $(P)$ concentration and density $(\rho)$ for $U K$ slurries $\diamond$, cattle slurry; $\triangle$, pig slurry; ,$- \quad P_{\text {cattle }}=4 \cdot 18 \rho-4037$ (fitted); ----, $\quad P_{\text {pig }}=31 \cdot 16 \rho-$ 31337 (fitted); percentage variance accounted for $35 \cdot 8 \%$,

$$
p<0 \cdot 01
$$

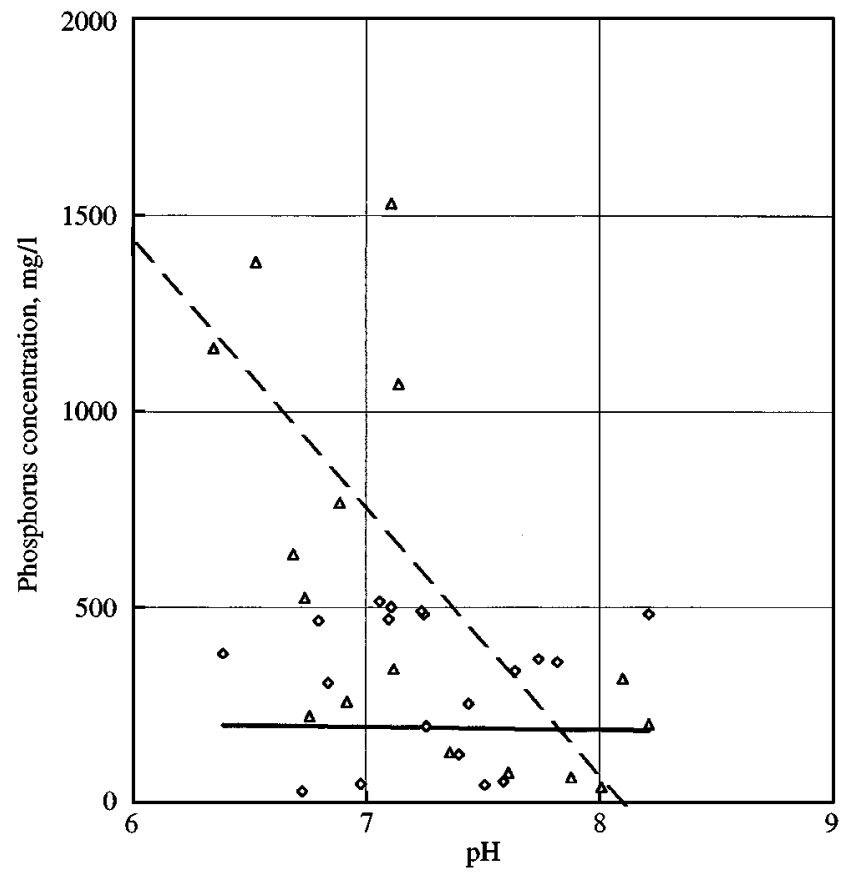

Fig. 10. Relationship between total phosphorus $(P)$ concentration and $\mathrm{pH}$ for $U K$ slurries $\diamond$, cattle slurry; $\triangle$, pig slurry; - , $P_{\text {cattle }}=-8 p H+248$ (fitted); ----, $P_{\text {pig }}=-688 p H+5571$ (fitted); percentage variance accounted for $45.6 \%, p<0.01$

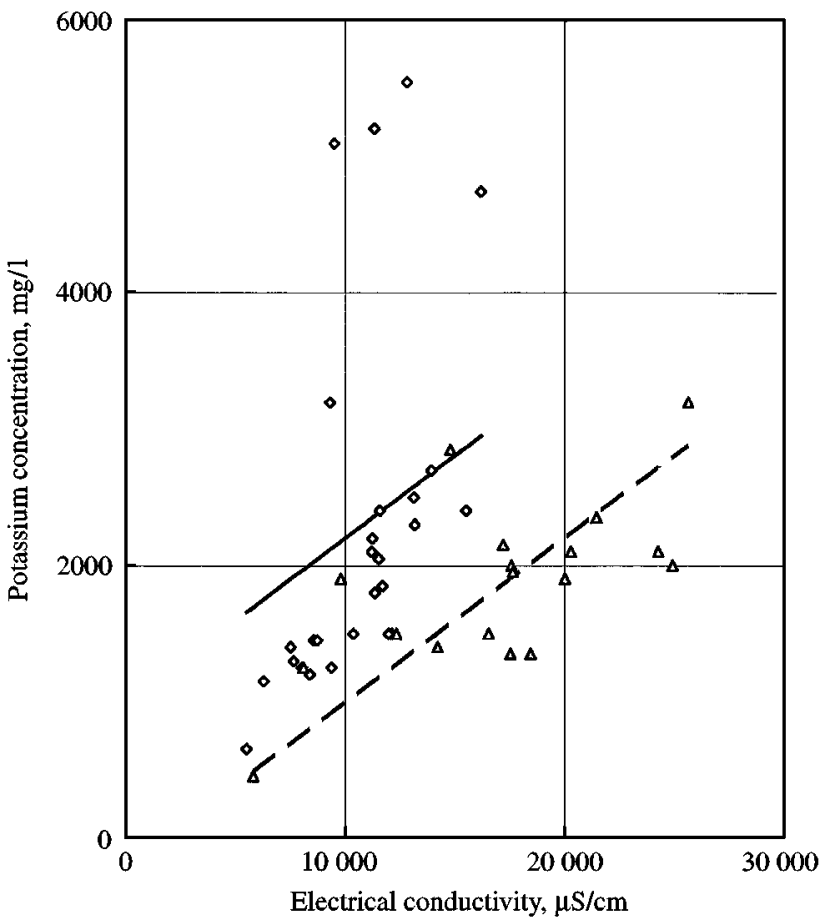

Fig. 11. Relationship between total potassium $(K)$ concentration and electrical conductivity (EC) for Irish slurries $\diamond$, cattle slurry; $\triangle$, pig slurry; $\longrightarrow, K_{\text {cattle }}=0.121 E C+992$ (fitted); ----, $K_{\mathrm{pig}}=0.121 E C-215$ (fitted); percentage variance accounted for $19.2 \%, p<0.01$ 
Table 6

Best fit multiple property regressions coefficients (and associated standard errors) for phosphorus

\begin{tabular}{|c|c|c|c|c|c|c|}
\hline \multirow{2}{*}{$\begin{array}{l}\text { slurry } \\
\text { type }\end{array}$} & \multicolumn{3}{|c|}{ Regression coefficients } & \multicolumn{2}{|c|}{ Measured properties } & \multirow[b]{2}{*}{$p v a(p)$} \\
\hline & $w$ & $x$ & $z$ & $C_{i}$ & $C_{j}$ & \\
\hline $\begin{array}{l}\text { United } \\
\text { Kingdom } \\
\text { cattle }\end{array}$ & $\begin{array}{l}4 \cdot 18 \\
(2 \cdot 11)\end{array}$ & $\begin{array}{c}5 \cdot 0 \\
(153)\end{array}$ & $\begin{array}{l}-4076 \\
(2454)\end{array}$ & \multirow{2}{*}{ density } & \multirow{2}{*}{$\mathrm{pH}$} & \multirow{2}{*}{$\begin{array}{c}67 \cdot 0 \\
(p<0 \cdot 01)\end{array}$} \\
\hline $\begin{array}{l}\text { United } \\
\text { Kingdom } \\
\text { Pigs }\end{array}$ & $\begin{array}{l}26 \cdot 09 \\
(5 \cdot 82)\end{array}$ & $\begin{array}{l}-619 \\
(105)\end{array}$ & $\begin{array}{l}-21734 \\
(6136)\end{array}$ & & & \\
\hline Irish cattle & $\begin{array}{l}-0 \cdot 311 \\
(0 \cdot 645)\end{array}$ & $\begin{array}{c}15 \cdot 1 \\
(11 \cdot 2)\end{array}$ & $\begin{array}{c}627 \\
(704)\end{array}$ & \multirow{2}{*}{ density } & \multirow{2}{*}{$\ln (k)$} & \multirow{2}{*}{$\begin{array}{c}69 \cdot 7 \\
(p<0 \cdot 01)\end{array}$} \\
\hline Irish pigs & $\begin{array}{l}74 \cdot 25 \\
(9 \cdot 33)\end{array}$ & $\begin{array}{l}-57 \cdot 0 \\
(21 \cdot 7)\end{array}$ & $\begin{array}{c}-75554 \\
(9627)\end{array}$ & & & \\
\hline $\begin{array}{l}\text { German } \\
\text { cattle }\end{array}$ & $\begin{array}{l}-1 \cdot 42 \\
(1 \cdot 94)\end{array}$ & $\begin{array}{l}-46 \cdot 2 \\
(21 \cdot 0)\end{array}$ & $\begin{array}{l}1819 \\
(2025)\end{array}$ & \multirow{2}{*}{ density } & \multirow{2}{*}{$\ln (k)$} & \multirow{2}{*}{$\begin{array}{c}89.8 \\
(p<0 \cdot 01)\end{array}$} \\
\hline $\begin{array}{l}\text { German } \\
\text { pigs }\end{array}$ & $\begin{array}{l}29 \cdot 22 \\
(5 \cdot 83)\end{array}$ & $\begin{array}{l}-46 \cdot 2 \\
(21 \cdot 0)\end{array}$ & $\begin{array}{l}-29097 \\
(6079)\end{array}$ & & & \\
\hline $\begin{array}{l}\text { Italian } \\
\text { cattle }\end{array}$ & $\begin{array}{c}4 \cdot 62 \\
(2 \cdot 77)\end{array}$ & $\begin{array}{l}-242 \cdot 8 \\
(67 \cdot 5)\end{array}$ & $\begin{array}{l}-2741 \\
(3011)\end{array}$ & \multirow{2}{*}{ density } & \multirow{2}{*}{$\mathrm{pH}$} & \multirow{2}{*}{$\begin{array}{c}82.0 \\
(p<0.01)\end{array}$} \\
\hline Italian pigs & $\begin{array}{l}21.06 \\
(1.93)\end{array}$ & $\begin{array}{l}-242 \cdot 8 \\
(67 \cdot 5)\end{array}$ & $\begin{array}{c}-19 \cdot 386 \\
(1997)\end{array}$ & & & \\
\hline
\end{tabular}

$\mathrm{p} v \mathrm{a}=$ percentage variance accounted for; $p=$ level of significance.

$\mathrm{pH}$ in the United Kingdom and Italy, whereas in Ireland and Germany they were with density and $\ln (k)$. In this case, the pva values associated with the regressions involving $\ln (k)$ were slightly better than those using $\mathrm{pH}$. Hence, in view of the known associations between $\mathrm{P}$ and $\mathrm{TS}$, and between TS and $\ln (k)$, the rheological property might be a better choice to achieve a standard approach for estimation in all countries. The best multiple property regressions for $\mathrm{K}$ were with $\mathrm{EC}$ and density in three of the countries; the United Kingdom was an exception: K related to $\mathrm{AI}$ and $\mathrm{pH}$. In this case, a standard estimation could be used for all four countries based on the regression of $\mathrm{K}$ with $\mathrm{EC}$ and density.

Overall, therefore the results showed that the best regressions involved single properties in some cases and multiple properties proved to be better for others. In a few situations, a single regression was found to provide the best fit to both cattle and pig slurries, whereas separate regressions were needed in most cases. Table 8 lists the properties that should ideally be included in an inline nutrient-sensing system. In the case of multiple property regressions, and in the interests of saving costs, careful consideration must be given to the degree of improvement achieved by measuring two properties instead of one. For example, the improvements in pva achieved for AN estimation by using multiple property regression over single property regression for Irish and Italian slurries were only $2 \cdot 8$ and $4 \cdot 6 \%$, respectively. Thus, this would not justify the extra expense and complication of measuring the additional property. However, the comparable improvements achieved for $\mathrm{P}$ estimation by using multiple property regression over single property regressions for United Kingdom and German slurries were 21.4 and $6.2 \%$, respectively, and thus measuring the extra property could be beneficial under these circumstances. For $\mathrm{K}$ estimation, the general relationships were weaker than for either AN or P; however, it is clear to see that the predicted values of $\mathrm{K}$ were strongly influenced by the electrical conductivities of the slurries.

The regression coefficients established were based on a wide range of slurries collected in each of the four countries. Previous evidence ${ }^{10}$ has shown that the prototype nutrient-sensing system is able to provide a good estimation of the dilution of a particular slurry. Thus, since the variability of nutrients in a particular slurry are mainly due to its dilution with water, it could be 


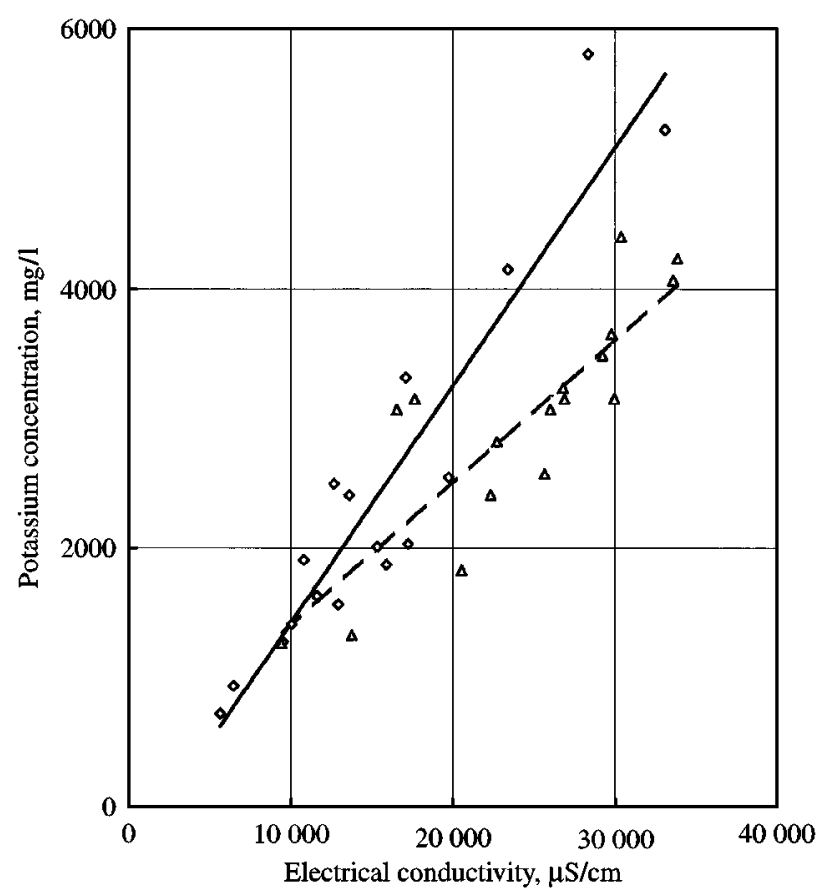

Fig. 12. Relationship between total potassium (K) concentration and electrical conductivity (EC) for German slurries $\diamond$, cattle slurry; $\triangle$, pig slurry;,$- K_{\text {cattle }}=0.184 E C-442$ (fitted); ----, $K_{\mathrm{pig}}=0.110 E C+306$ (fitted); percentage variance accounted for $80.0 \%, p<0 \cdot 01$

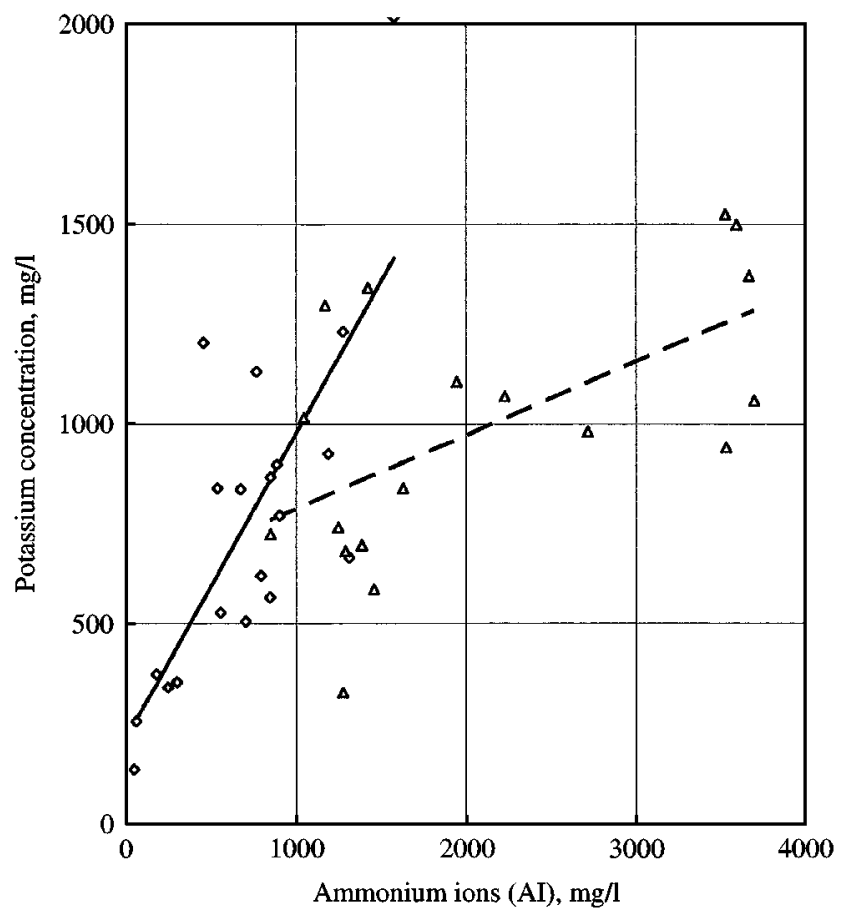

Fig. 13. Relationship between total potassium $(K)$ concentration and ammonium ions (AI) for UK slurries $\diamond$, cattle slurry; $\triangle$, pig slurry;,$- K_{\text {cattle }}=0.763 \mathrm{AI}+212$ (fitted); ----, $K_{\text {pig }}=0 \cdot 184$ $A I+603$ (fitted); percentage variance accounted for $50 \cdot 2 \%$, $p<0 \cdot 01$

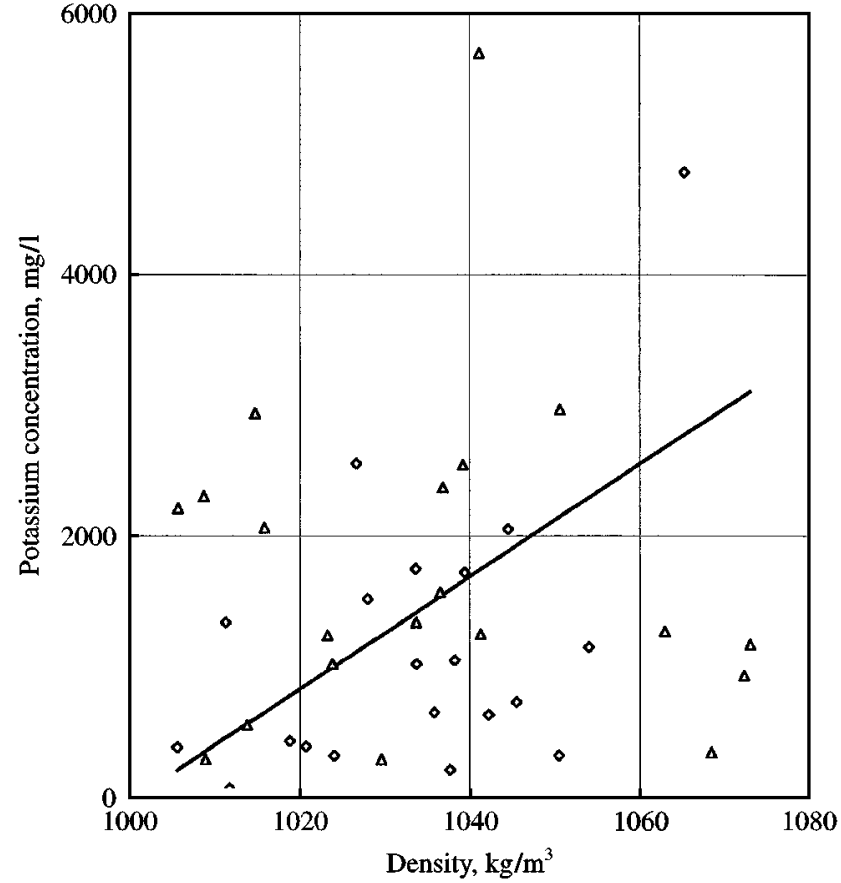

Fig. 14. Relationship between total potassium (K) concentration and density $(\rho)$ for Italian slurries $\diamond$, cattle slurry; $\triangle$, pig slurry; $\longrightarrow, K_{\text {cattle and pig }}=42.97 \rho-43000$ (fitted) percentage variance accounted for $42 \cdot 4 \%, p<0 \cdot 01$

postulated that re-calibrating the nutrient-sensing system on a smaller range of slurries or even on an individual farm or store basis would improve the accuracy of the system. Clearly, nutrient estimation techniques incorporated on the tanker would enable the contents of a store to be analysed load by load during normal spreading operations, thus eliminating the errors associated with sub-sampling from a large store. This study has shown that it is feasible to develop a nutrient-sensing system that could be used on a slurry tanker to fulfil this role.

\section{Conclusions}

1. Data from the United Kingdom, Ireland and Germany indicated strong single property relationships between ammoniacal nitrogen and electrical conductivity with percentage variance accounted for (pva) values of $84 \cdot 1,80 \cdot 6$ and $91 \cdot 9 \%$, respectively. Data from Italy also indicated a single property, but weaker, relationship between the two (pva value of $39 \cdot 1 \%$ ).

2. Multiple property regressions for the prediction of ammoniacal nitrogen concentrations which combined electrical conductivity with density or with the rheological parameter $\ln (k)$, produced significantly 
Table 7

Best fit multiple property regressions coefficients (and associated standard errors) for potassium

\begin{tabular}{|c|c|c|c|c|c|c|}
\hline \multirow{2}{*}{$\begin{array}{l}\text { slurry } \\
\text { type }\end{array}$} & \multicolumn{3}{|c|}{ Regression coefficients } & \multicolumn{2}{|c|}{ Measured properties } & \multirow[b]{2}{*}{$p v a(p)$} \\
\hline & $w$ & $x$ & $z$ & $C_{i}$ & $C_{j}$ & \\
\hline $\begin{array}{l}\text { United } \\
\text { Kingdom } \\
\text { cattle }\end{array}$ & $\begin{array}{c}0.746 \\
(0.159)\end{array}$ & $\begin{array}{c}36.0 \\
(89.2)\end{array}$ & $\begin{array}{l}-37 \\
(629)\end{array}$ & \multirow{2}{*}{$\begin{array}{c}\text { Ammonium } \\
\text { ions }\end{array}$} & \multirow{2}{*}{$\mathrm{pH}$} & \multirow{2}{*}{$\begin{array}{c}49.0 \\
(p<0.01)\end{array}$} \\
\hline $\begin{array}{l}\text { United } \\
\text { Kingdom } \\
\text { Pigs }\end{array}$ & $\begin{array}{c}0.188 \\
(0.067)\end{array}$ & $\begin{array}{c}36.0 \\
(89.2)\end{array}$ & $\begin{array}{c}338 \\
(674)\end{array}$ & & & \\
\hline Irish cattle & $\begin{array}{c}0 \cdot 300 \\
(0 \cdot 075)\end{array}$ & $\begin{array}{l}-4 \cdot 61 \\
(2 \cdot 78))\end{array}$ & $\begin{array}{c}4080 \\
(2862)\end{array}$ & Electical & \multirow{2}{*}{ density } & \multirow{2}{*}{$\begin{array}{c}27 \cdot 9 \\
(p<0.01)\end{array}$} \\
\hline Irish pigs & $\begin{array}{c}0 \cdot 0754 \\
(0 \cdot 0416)\end{array}$ & $\begin{array}{l}-4 \cdot 61 \\
(2 \cdot 78)\end{array}$ & $\begin{array}{c}5272 \\
(2916)\end{array}$ & Conductivity & & \\
\hline $\begin{array}{l}\text { German } \\
\text { cattle }\end{array}$ & $\begin{array}{c}0 \cdot 184 \\
(0 \cdot 016)\end{array}$ & $\begin{array}{c}9 \cdot 25 \\
(4 \cdot 59)\end{array}$ & $\begin{array}{c}-10052 \\
(4784)\end{array}$ & \multirow{2}{*}{$\begin{array}{c}\text { Electrical } \\
\text { conductivity }\end{array}$} & \multirow{2}{*}{ density } & \multirow{2}{*}{$\begin{array}{c}84 \cdot 8 \\
(p<0 \cdot 01)\end{array}$} \\
\hline $\begin{array}{l}\text { German } \\
\text { pigs }\end{array}$ & $\begin{array}{c}0 \cdot 094 \\
(0 \cdot 018)\end{array}$ & $\begin{array}{c}9 \cdot 25 \\
(4 \cdot 59)\end{array}$ & $\begin{array}{l}-8795 \\
(4606)\end{array}$ & & & \\
\hline $\begin{array}{l}\text { Italian } \\
\text { cattle }\end{array}$ & $\begin{array}{c}0 \cdot 066 \\
(0 \cdot 018)\end{array}$ & $\begin{array}{l}34 \cdot 93 \\
(7 \cdot 21)\end{array}$ & $\begin{array}{c}-35 \cdot 683 \\
(7380)\end{array}$ & \multirow{2}{*}{$\begin{array}{c}\text { Electrical } \\
\text { conductivity }\end{array}$} & \multirow{2}{*}{ density } & \multirow{2}{*}{$\begin{array}{c}56 \cdot 4 \\
(p<0 \cdot 01)\end{array}$} \\
\hline Italian pigs & $\begin{array}{c}0.066 \\
(0 \cdot 018)\end{array}$ & $\begin{array}{l}34 \cdot 93 \\
(7 \cdot 21)\end{array}$ & $\begin{array}{c}-35683 \\
(7380)\end{array}$ & & & \\
\hline
\end{tabular}

$\mathrm{p} v \mathrm{a}=$ percentage variance accounted for; $p=$ level of significance.

improved pva values of $83 \cdot 4$ and $50 \cdot 1 \%$, respectively, in Ireland and Italy. Corresponding improvements in the United Kingdom and Germany were not significant.

3. Data from Ireland, Germany and Italy indicated strong single property relationships between phosphorus and density (pva values of $64 \cdot 8,83 \cdot 6$ and $76 \cdot 1 \%$, respectively). Data from United Kingdom also indicated a single property, but weaker relationship between the two (pva value of $35.8 \%$ ).

4. Multiple property regressions produced significant increases in pva values for phosphorus predictions in all four countries. Density and $\mathrm{pH}$ was the best combination in the United Kingdom and Italy (pva values of 67.0 and $82.0 \%$, respectively). Density and the rheological parameter $\ln (k)$ was the best combination

Table 8

Measured slurry properties which provided best fit relationship s for ammoniacal nitrogen (AN), total phosphorus (P) and total potassium $(\mathbf{K})$ in each of the four countries

\begin{tabular}{|c|c|c|c|}
\hline Country & Ammoniacal nitrogen (AN), $\mathrm{mg}$ & Total phosphorus (P), mg & Total potassium (K), $\mathrm{mg}$ \\
\hline United Kingdom & Electrical conductivity & Density and pH & Ammonium ions \\
\hline Ireland & $\begin{array}{l}\text { Electrical conductivity } \\
\text { and density }\end{array}$ & Density and $\ln (k)$ & Electrical conductivity \\
\hline Germany & Electrical conductivity & Density and $(k)$ & $\begin{array}{c}\text { Electrical conductivity } \\
\text { and density }\end{array}$ \\
\hline Italy & $\begin{array}{l}\text { Electrical conductivity } \\
\text { and } \ln k\end{array}$ & Density and $\mathrm{pH}$ & $\begin{array}{c}\text { Electrical conductivity } \\
\text { and density }\end{array}$ \\
\hline
\end{tabular}

Note: $\ln (k)$ was derived from the measurement of slurry flow and the corresponding pressure gradient in a pipe. 
in Ireland and Germany (pva values of $69 \cdot 7$ and $89.8 \%$, respectively).

5. In the United Kingdom, Ireland and Italy, the regressions for potassium were weaker than those for either ammoniacal nitrogen or phosphorus, with any of the measured properties. The best-fit relationships had pva values of $50 \cdot 2,19 \cdot 2$ and $42 \cdot 4 \%$, respectively. Germany was the exception to this, a multiple property regression with electrical conductivity and density led to a pva value of $84 \cdot 8 \%$.

6. Forecast standard errors for nutrient estimation ranged from \pm 375 to $\pm 801 \mathrm{mg} / \mathrm{l}$ for ammoniacal nitrogen; from \pm 185 to $\pm 322 \mathrm{mg} / \mathrm{l}$ for phosphorus and from \pm 297 to $\pm 1084 \mathrm{mg} / \mathrm{l}$ for potassium.

7. The information determined in this investigation provides strong evidence that an in-line nutrient-sensing system could be designed and built for use on a slurry tanker, thus enabling nutrient estimation on a tanker by tanker basis, and reducing sampling errors.

8. A prototype in-line nutrient-sensing system should include sensors for electrical conductivity (for ammoniacal nitrogen determination); density, $\ln (k)$ (based on measurement of slurry flow and corresponding pressure gradient in a pipe) and $\mathrm{pH}$ (for total phosphate determination); and electrical conductivity, density and ammonium ions (for total potassium determination).

\section{Appendix 1: Statistical procedures used for selection of appropriate regression equations}

The first stage of the analysis was concerned with establishing the most effective single property regressions, i.e. regressions of each of the measured nutrient concentrations ( $\mathrm{AN}, \mathrm{P}$ and $\mathrm{K}$ ) with each one of the measured properties. The second stage extended the analysis to include two measured properties using a multiple regression technique.

\section{Single property regression}

The data were analysed as four separate groups: each group included data from only one of the four countries included in the experiments. For each group of data, the regression analysis considered the following cases representing increasing numbers of parameters: (a) single regression line, i.e. same slope and intercept for both cattle and pig slurries; (b) parallel regression lines for each slurry type, i.e. same slope but separate intercepts; and (c) separate regression lines, i.e. separate slopes and separate intercepts. The main principles of this process are outlined below. (i) Each group of data, comprising two slurry types (i.e. cattle and pig) was used to evaluate the coefficients $w$ and $z$ defined in Eqn (2) for each of the three regression cases. This procedure was applied separately for each of the 3 key slurry nutrients (AN, P and K), based on each of the measured properties.

(ii) Each regression case produced an equation or equations which represented the variation in values of nutrient concentration as a linear function of a measured property. The sums of squares (SS) of the deviations of these values from the mean of the measured values of each nutrient concentration were evaluated for the regression equations representing each of the regression cases. These were represented in a cumulative form to show the amount by which each additional inclusion of another parameter to the regression contributed to the total sum of squares of the deviations of the measured values of nutrient concentration about their mean value. In addition, the sum of squares of the deviations of the measured values of nutrient concentration from the regression equations corresponding to regression case (c) were also calculated. In the context of this analysis, this was termed the residual sum of squares (RSS). The calculation of these sums of squares provided the first step towards completion of a summary analysis of the variance table, as illustrated in Table A1.

The second column of Table A1 lists the number of degrees of freedom (df) associated with each regression parameter and with the residual. The ratio of the SS values to the corresponding degrees of freedom enabled calculation of mean square deviation (MS) values, as shown in column four of Table A1.

(iii) In general, and as expected, the analysis of variance showed that inclusion of more parameters reduced the SS values. However, the selection of the appropriate regression case was not simple based on choosing the regression case which resulted in the smallest SS value. Instead, the alternative regression cases were compared by evaluating the ratios of their MS values to the residual MS value, (i.e. variance ratios, as shown in column five of Table A1). The significance of these ratios was then determined using standard tables of the variance ratio $(F)$ statistic (column six, Table A1).

(iv) In those cases where the Fpr value corresponding to regression case (c) was less than $5 \%$, the latter was selected as the most appropriate regression model. If this condition was not satisfied, then the regression case (b) was selected if $\mathrm{Fpr}_{(\mathrm{b})}$ was less 
Table A1

Example analysis of variance table illustrating methods of selection of appropriate regression equation

\begin{tabular}{|c|c|c|c|c|c|}
\hline Parameter & $\begin{array}{l}\text { Number of } \\
\text { degrees of } \\
\text { freedom }(d f)\end{array}$ & $\begin{array}{l}\text { Sum of } \\
\text { squares of } \\
\text { deviations } \\
\text { (SS) }\end{array}$ & $\begin{array}{l}\text { Mean } \\
\text { square } \\
\text { deviation } \\
(M S)\end{array}$ & $\begin{array}{l}\text { Variance ratio } \\
(F)\end{array}$ & $\begin{array}{l}\text { Probability } \\
\text { (Fpr) }\end{array}$ \\
\hline $\begin{array}{l}\text { Electrical conductivity, represent- } \\
\text { ing regression case (a) }\end{array}$ & 1 & $A$ & $A / 1$ & $(A / 1) /(D /(n-4))$ & $(\mathrm{Fpr})_{(\mathrm{a})}$ \\
\hline $\begin{array}{l}\text { Type of slurry, i.e. cattle or pig, } \\
\text { representing regression case (b) }\end{array}$ & 1 & $B$ & $B / 1$ & $(B / 1) /(D /(n-4))$ & $(\mathrm{Fpr})_{(\mathrm{b})}$ \\
\hline $\begin{array}{l}\text { Type of slurry and electrical } \\
\text { conductivity, representing } \\
\text { regression case (c) }\end{array}$ & 1 & C & $C / 1$ & $(C / 1) /(D /(n-4))$ & $(\mathrm{Fpr})_{(\mathrm{a})}$ \\
\hline $\begin{array}{l}\text { Residual, i.e. variation in } \\
\text { measured values of nutrient } \\
\text { concentration not accounted } \\
\text { for by regression case (c) }\end{array}$ & $n-4$ & $D$ & $D /(n-4)$ & - & - \\
\hline Total & $n-1$ & $A+B+C+D$ & - & - & - \\
\hline
\end{tabular}

than $5 \%$. If this second condition was not satisfied, then regression case (a) was chosen.

(v) Finally, a value was calculated for the percentage variance accounted for (pva) corresponding to the selected regression. Since the analysis considered the type of slurry (i.e. cattle or pig) as a variable, a single value of pva was determined for each country's data, appropriate to each of the key nutrients.

\section{Multiple property regression}

This procedure was similar to that followed for the single property regressions, although the analysis considered the three regression cases independently in connection with each of two measured properties. Thus, a total of nine combinations of regression cases were included in each analysis of variance.

\section{Acknowledgements}

This work was funded by the European Commission in the context of the "Sustainable Waste Application Management Project" (SWAMP). The authors gratefully acknowledge the help of their colleagues in Silsoe Research Institute, United Kingdom; Teagasc, Ireland; LUFA, Germany, UDSM, Italy; Algosystems SA, Greece; SAC, Scotland; IMAG, The Netherlands and JTI, Sweden, in the execution of this work.

Our thanks also go to many farmers in United Kingdom, Ireland, Germany and Italy for their cooperation, and for supplying the slurry samples that allowed this study to be completed.

\section{References}

1 Ministry of Agriculture Fisheries and Food Fertilizer Recommendations for Agricultural and Horticultural Crops. Reference Book 209, London; MAFF Publications, 1993

2 Ministry of Agriculture, Fisheries and Food Code of Good Agricultural Practice for the Protection of Air. Publication PB0618, London: MAFF, 1992

3 Ministry of Agriculture, Fisheries and Food Code of Good Agricultural Practice for the Protection of Water. Publication PB0507, London: MAFF, 1991

${ }^{4}$ Ministry of Agriculture, Fisheries and Food Code of Good Agricultural Practice for the Protection of Soil. Publication PB0617, London: MAFF, 1993

${ }^{5}$ Kellerup V Agros nitrogen meter for estimation of ammonium nitrogen in slurry and liquid manure. In: Efficient Land Use of Sludge and Manure (Dam Kofoed A; Williams J H; L'Hermite P eds), pp. 216-223 Barking: Elsevier Applied Science Publishers, 1985

${ }^{6}$ Smith K A; Nicholson R J; Williams J R; Chamber B J A review of rapid methods for assessing the nutrient content of organic manures. ADAS Report to MAFF Environmental Protection Division, Project Number WA 0605, 1993

7 Tunney H; Bertrand M Rapid field tests for estimating dry matter and fertilizer value of animal slurries. In: Land and Water Use (Dodd V A; Grace P M eds), pp. 363-370, Rotterdam: Balkema, 1989

${ }^{8}$ Stevens R J; O'Bric C; Carton O T Estimating nutrient content of animal slurries using electrical conductivity. Journal of Agricultural Science, Cambridge, 1995, 125, 233-238

9 Westerman P W; Safley L M; Barker J C Lagoon liquid nutrient variation over four years for lagoons with recycle systems. In: Aricultural and Food Processing Waste, Proceedings of the 6th International Symposium on Agricultural and Food Processing Wastes, Chicago, 17-18 December 1990, 41-49

10 Scotford I M; Cumby T R; Richards P A; Han L Development of a prototype nutrient sensing system for livestock slurries. Journal of Agricultural Engineering Research, 1998, 69, 217-228 
11 Scotford I M; Cumby T R; Richards P A; Han L Sustainable waste application management project. In-situ nutrient sensor using guide. Contract Report CR/707/96/8313, Silsoe Research Institute, 1996

12 Ministry of Agriculture Fisheries and Food Fertiliser Recommendations for Agricultural and Horticultural Crops. Reference Book 209, London: MAFF Publication, 1993
${ }^{13}$ Hester W Aspects of the aerobic processing of agricultural waste slurries. PhD thesis, Magdalene College, University of Cambridge, 1987

14 Genstat 5 Committe Genstat 5 Release 3 Reference Manual. Oxford: Clarendon Press, 1993.

15 Snedecor G W; Cochran W G Statistical Methods, 6th edn. Iowa: Iowa State University Press, 1967 